\title{
A new method to estimate air-quality levels using a synoptic-regression approach. Part II: Future $\mathrm{O}_{3}$ concentrations
}

\author{
Matthias Demuzere*, Nicole P.M. van Lipzig \\ Earth and environmental Sciences, Celestijnenlaan 200E, 3001 Heverlee (Leuven), Katholieke Universiteit Leuven, Belgium
}

\section{A R T I C L E I N F O}

\section{Article history:}

Received 23 December 2008

Received in revised form

5 June 2009

Accepted 10 June 2009

\section{Keywords:}

Synoptic-regression based statistical

downscaling

Objective Lamb weather types

Future $\mathrm{O}_{3}$ levels

ECHAM5-MPI/OM

\begin{abstract}
A B S T R A C T
Using the synoptic-regression based approach developed in Part I of this research, this study estimates future maximum 8 hourly mean $\mathrm{O}_{3}$ levels $\left(\mathrm{m} 8 \mathrm{hO}_{3}\right)$ using three future SRES (Special Report on Emission) scenarios for a rural background area situated in The Netherlands. The statistical downscaling tool was used to downscale the Atmospheric-Ocean Coupled General Circulation Model (AOGCM) ECHAM5-MPI/OM for the present-day 20 Century (20C) control run (1991-2000) and the future SRES scenarios A2, A1B and B1 for two periods (2051-2060 and 2091-2100). First, the statistical downscaling tool is evaluated in terms of downscaled $\mathrm{m} 8 \mathrm{hO}_{3}$ levels for the present-day climate, using a long record of observed $\mathrm{m} 8 \mathrm{hO}_{3}$ concentrations. It was found that a bias correction is needed and this bias correction is then further used to estimate future $\mathrm{m} 8 \mathrm{hO}_{3}$ concentrations. Under the various SRES scenarios, the overall mean $\mathrm{m} 8 \mathrm{hO}_{3}$ increases with 2.5-6.5 and $6.1-10.9 \mu \mathrm{g} \mathrm{m}^{-3}$, for the 2051-2060 and 2091-2100 period respectively, which is about $20 \%$ of the present-day 10-year average. This effect is enhanced when considering the summer season only, with a range of increase between the different future scenarios of 5.4-12.5 $\mu \mathrm{g} \mathrm{m}^{-3}$ and 13.4-26 $\mu \mathrm{g} \mathrm{m}^{-3}$ (for 2051-2060 and 2091-2100 respectively) against a present-day summer average of $73.5 \mu \mathrm{g} \mathrm{m}^{-3}$. An increase in maximum temperature and shortwave radiation, associated with a decrease in cloud cover under the various future scenarios are the main drivers of ozone increase. A comparison with August 2003 shows the physical plausibility of our results and reflects that the extreme summer of 2003 might show a close resemblance to future European summers in terms of $\mathrm{m} 8 \mathrm{hO}_{3}$ and meteorological characteristics.
\end{abstract}

(c) 2009 Elsevier Ltd. All rights reserved.

\section{Introduction}

Over the past 20 years, levels of ozone have been a concern to policy makers in Europe, as observed $\mathrm{O}_{3}$ levels continue to exceed internationally accepted guidelines for the protection of human health and vegetation in the spring and summer months (EU, 2008). Since the $\mathrm{NO}_{x}$ and VOC protocols of the United Nations Economic Commission for Europe (UN ECE) Convention on Longrange Transboundary Air Pollution (CLRTAP) almost 20 years ago, downward trends in VOC and $\mathrm{NO}_{x}$ have been observed. As a consequence, also episodic peak ozone levels decreased over parts of north-west Europe (Derwent et al., 2003). Despite these reductions in episodic peak levels, ozone levels are still a cause for concern during in the 21st century and air-quality guidelines are still exceeded in most years in some EU countries. In this respect, the question is whether further regional pollution control strategies will be stringent enough to reduce the overall ozone levels in Europe to its postulated levels.

\footnotetext{
* Corresponding author. Tel.: +32 16326424; fax: +32 16326400.

E-mail address: matthias.demuzere@ees.kuleuven.be (M. Demuzere).
}

Future air-quality levels will be affected by several factors including changing biogenic and anthropogenic emissions, (intercontinental) long-range transport and possible changes in the regional climate (Derwent et al., 2003). In this respect, projections from AOGCMs (Atmospheric-Ocean Coupled Global Climate Models) are commonly used as scenarios of future climate in the twenty-first century. Unfortunately, the resolution of these global climate models exceeds the impact assessors' needs, which often requires information equivalent to point observations. Therefore, a downscaling approach is used to bridge the gap between what AOGCMs produce and what impact assessors require. Hewitson and Crane (1996) suggested two categories of downscaling methods: process-based (dynamical) techniques, involving the explicit solving of the physical dynamics of the system and empirical (statistical) techniques that use the identified relationships derived from observational data. Dynamic and statistical downscaling techniques are complimentary and both methods should be used to evaluate future ozone levels (Mahmud et al., 2008). Giorgi and Meleux (2007) have shown that the complex climate-air quality modelling-systems, together with their computational/technical characteristics, make dynamical downscaling methods less useful for long-term predictions based on 
AOGCM outputs. Therefore, statistical downscaling methods are useful in terms of temporal and spatial computational requirements.

This study uses the synoptic-regression based approach, presented in Part I of this paper (Demuzere and van Lipzig, in press). The statistical tool applies a circulation pattern classification prior to the multiple regression analysis and is in first instance evaluated in terms of downscaled maximum eight hourly ozone concentrations for the present-day climate (calculated as the daily maximum of the 8 -hourly running mean - hereafter referred to as $\mathrm{m}^{8} \mathrm{hO}_{3}$ ). The synoptic-regression based relationships between meteorology and observed ${\mathrm{m} 8 \mathrm{hO}_{3}}_{3}$ are built on present-day data (see Part I) and therefore intrinsically include present-day precursor emission information. The effect of future biogenic and anthropogenic emissions and their feedbacks onto the physic-chemical formation processes of ozone under future climate conditions is at present still uncertain. For example, a decrease of relative humidity together with an increase of the photolysis rate, due to a decrease in cloud cover (Meleux et al., 2007), could lead to a lower production of $\mathrm{OH}$ radicals, suggesting a decrease of ozone formation with a decrease of $\mathrm{OH}$. On the other hand, the $\mathrm{O}_{3}$ removal by the process of $\mathrm{NO}_{x}$ titration will decrease (Sillman, 1999). These features cannot be explained using a statistical downscaling tool, but should be further investigated with state-ofthe-art chemical transport models. Therefore, the same relations are kept to statistically downscale possible future climate scenarios. In doing so, we assume that the present-day relations between meteorology and air-quality variables stay constant through time. Moreover, when applying these techniques for future air-quality projections, we aim to identify the impact of meteorological changes on future $\mathrm{m} 8 \mathrm{hO}_{3}$ solely, without taking into account possible changes in future (precursor) emissions.

\section{Datasets}

\subsection{Air-quality data}

In order to evaluate the downscaled $\mathrm{m} 8 \mathrm{O}_{3}$ time series using AOGCM present-day meteorological variables, one needs a long enough homogeneous maximum eight-hourly mean ozone record. As the Air Quality Monitoring Network of RIVM (National Institute of Public Health and Environment) is measuring ozone in The Netherlands since the 70s, this dataset is available. Inconsistencies in the dataset due to a change in for e.g. monitoring aspects, anthropogenic emissions and quality control are checked with a standard normal homogeneity test (SNHT) of the form of Alexandersson and Moberg (1997) and a Mann-Kendall test. A critical value of the SNHT statistic $\mathrm{T}$ of 14.94 is used on the $99 \%$ significance interval, as suggested by Khaliq and Ouarda (2007) for a sample size of 7500 elements. According to this analysis, a change point is detected in 1984 and 1990. Furthermore, the Mann-Kendall test shows there is no significant trend for the period 1991-2000. Hence, this period from 1991 to 2000 will be used as the present-day reference period.

\subsection{Meteorological data}

The AOGCM used in this study consists of the model versions ECHAM5 and MPI/OM for both the atmosphere and the ocean respectively, which are used in the framework of the 4th IPCC assessment report. The atmosphere model ECHAM5 is described in detail in Roeckner et al. (2003) while more information on the ocean model (MPI/OM) can be found in Marsland et al. (2003). In the coupled model (Jungclaus et al., 2006), the ocean passes the sea surface temperature, sea ice concentration, sea ice thickness, snow depth on ice, and the ocean surface velocities to the atmosphere. The atmosphere runs with these boundary values for one coupling time step (one day) and accumulates the (non-adjusted) forcing fluxes.
In order to evaluate the synoptic-regression based downscaling tool as developed in Part I, observed present-day (1991-2000) $\mathrm{m} 8 \mathrm{hO}_{3}$ levels are reconstructed based on present-day meteorology from the ECHAM5 SRES 20C control run with greenhouse gasses increasing as observed through the 20th century. The suite of meteorological variables described in Part I are extracted four times daily $(0,6,12,18$ UTC) at a T63L31 resolution for four neighboring grid points $\left(3.75-5.62^{\circ} \mathrm{E}, 51.29-53.15^{\circ} \mathrm{N}\right)$ around the Cabauw measurement station (cf. Demuzere and van Lipzig, in press; Demuzere et al., 2009). Except the minimum and maximum daily temperature $\left(T_{\min } / T_{\max }\right)$, all variables are averaged to daily mean values whereby the relative humidity $(\mathrm{RH})$ is calculated from T and Td using the Magnus-Tetens approximation. The ECHAM5 12UTC sea level pressure (SLP) data used to derive the objective Lamb circulation patterns as described in Section 3 is selected on the larger European-Atlantic Region $\left(27.5^{\circ} \mathrm{W}-27.5^{\circ} \mathrm{E}, 15^{\circ} \mathrm{N}-85^{\circ} \mathrm{N}\right)$ on a T63L31 resolution. Future simulation from ECHAM5-MPI/OM are done in the framework of the 4th IPCC assessment report and include the SRES scenarios A1B, B1 and A2 Nakicenovic and Swart (2000) between the years 2001 and 2100 on a 6-hourly temporal resolution.

Unfortunately, measurements of the predictor variables are not available from the Cabauw measurement site for the period 1991-2000. However, in order to evaluate the downscaled ECHAM5 $\mathrm{m} 8 \mathrm{hO}_{3}$ time series for the present-day climate, the ECMWF - ERA40 reanalysis data (hereafter referred to as ERA40) (Uppala et al., 2005) can be used as a reference dataset, although it has to be taken into account that this dataset also has uncertainties in its surface meteorological variables (e.g. Part I). The ERA40 sea level pressure (SLP) is selected for the same European Atlantic region on a $2.5^{\circ} \times 2.5^{\circ}$ grid using the 12UTC time step. Similar, all meteorological variables are obtained from ERA40 for the period 1991-2000 on a 6-hourly resolution, for 4 neighboring grid points on a $1 \times 1^{\circ}$ resolution $\left(4-5^{\circ} \mathrm{E}, 51-52^{\circ} \mathrm{N}\right)$. All variables are reduced to their daily means, except for the daily maximum and minimum temperature. To study the effect of the horizontal resolution, ERA40 reanalysis data is also extracted from the original ERA40 N80 reduced Gaussian resolution for the single nearest neighboring grid point to the Cabauw measurement station (hereafter referred to as ERA40-1).

\section{Methods}

The synoptic-regression tool applies a circulation pattern classification prior to the multiple regression analysis in order to introduce a non-linearity, thus meaning a stratification of the data in terms of a set of circulation patterns. The classification is done as described in Part I and following Demuzere et al. (2008) using gridded SLP data in 16 grid points assigned over the larger Western and Central European region (Fig. 1). Indices referring to the direction of vorticity and geostrophic flow are then calculated daily from the 12UTC SLP values in these 16 grid points. A small number of empirical rules devised previously (Jones et al., 1993) are used to classify each day as one of the 27 circulation types. Afterwards, all daily types are clustered according to their preferential geostrophic wind direction, as was done in Demuzere et al. (2009).

Secondly, for each circulation pattern and season, a regression equation is developed based on the suite of meteorological variables shown in Table 1 of Part I of this research. As an example, the linear relationships between the three most important JJA predictor variables and observed $\mathrm{m} \mathrm{hO}_{3}$ within a group of circulation patterns contributing to high ozone concentrations are shown in Fig. 2. The predictor variables are grouped for the Anticyclonic (A), E (east), SE (southeast) and S (southern) circulation patterns and only shown for JJA as an example. The maximum temperature has the strongest linear relation with $\mathrm{m} 8 \mathrm{hO}_{3}\left(R^{2}=0.58\right)$, followed by 


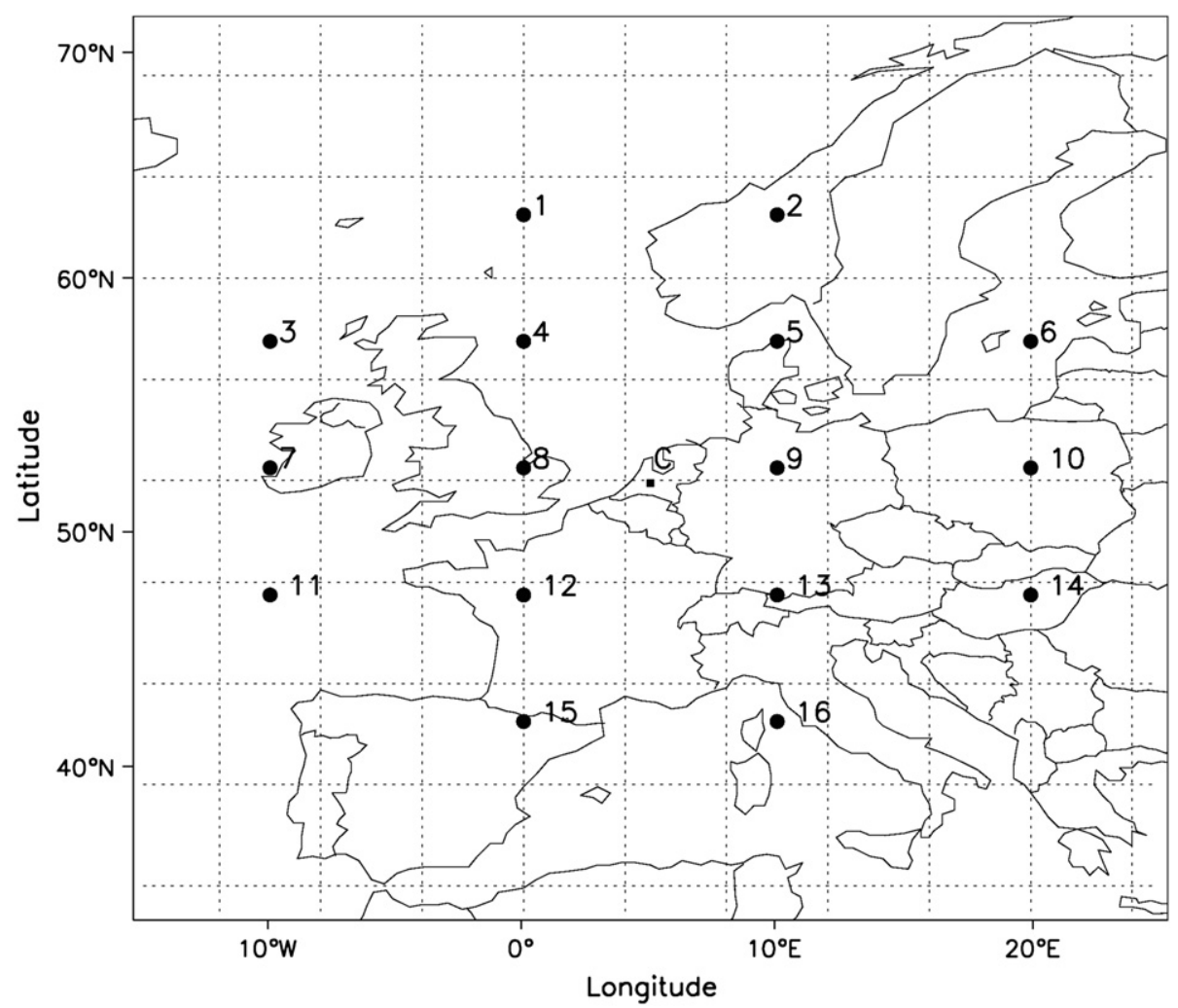

Fig. 1. Location of the $5^{\circ} \times 10^{\circ}$ SLP grid used, with 16 point centered over the Benelux. "C" denotes the location of the Cabauw measurement station and the grid center.

a negative correlation for relative humidity $\left(R^{2}=0.51\right)$. Furthermore, an increase in shortwave downward radiation (SWD) positively influences the photochemical production of ozone with a positive linear correlation of $R^{2}=0.23$ (Fig. 2). For more details on the calibration and evaluation of this synoptic-regression downscaling approach, the reader is referred to Part I of this paper.

The analysis in Part I reveals that a stratification of the dataset using the automated Lamb weather type scheme, prior to a multiple linear regression analysis improves the downscaling results for $\mathrm{m} 8 \mathrm{hO}_{3}$ in terms of explained variances and skill score against a reference model. Here, the reference is taken from numerical weather prediction and describes persistence, i.e., the previous value in a sequence of observations (Wilks, 1995). More information on the evaluation of the method and a detailed description of the statistical indices can be found in Section 3 of Part I of this research.

Part II of this analysis applies the synoptic-regression based downscaling tool for present-day conditions based on daily mean ECHAM5 meteorological data. Afterwards, the same approach is followed to downscale future levels of $\mathrm{m} \mathrm{hO}_{3}$ based on the ECHAM5 SRES A2, A1B and B1 scenarios for two selected future periods
2051-2060 and 2091-2100. Thereby, the relationships derived from the present period 2001-2006 (Part I) are assumed to remain constant in the future and future changes in biogenic and anthropogenic (precursor) emissions are not explicitly taken into account.

\section{Results}

In this section, results of the statistical downscaling of presentday and future AOGCM data in terms of $\mathrm{m} \mathrm{hO}_{3}$ are discussed. As the circulation patterns are an important factor in the statistical downscaling approach (Demuzere et al., 2009), present-day circulation patterns derived from ECHAM5 SLP are evaluated with the circulation patterns derived from ERA40 SLP fields (Section 4.1). Secondly, the synoptic-regression based statistical downscaling tool is applied on the present-day meteorological variables from ECHAM5 and compared to the observed $\mathrm{m} 8 \mathrm{hO}_{3}$ time series at the Cabauw monitoring station for the period 1991-2000 (Section 4.2). Finally, future $\mathrm{m} 8 \mathrm{hO}_{3}$ estimates are done based on ECHAM5 future A2, A1B and B1 scenarios for the periods 2051-2060 and 2091-2100 (Section 4.3).

Table 1

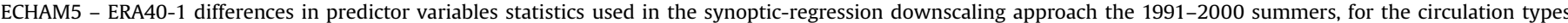

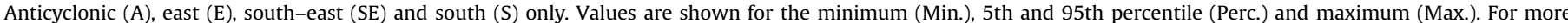
information on the circulation type - dependent predictor variables, the reader is referred to Part I of this analysis.

\begin{tabular}{|c|c|c|c|c|c|c|c|c|c|c|c|}
\hline & \multicolumn{3}{|l|}{ A } & \multicolumn{2}{|l|}{ E } & \multicolumn{2}{|l|}{ SE } & \multicolumn{4}{|l|}{ S } \\
\hline & SWD $\left[\mathrm{W} \mathrm{m}^{-2}\right]$ & $T_{\max }\left[{ }^{\circ} \mathrm{C}\right]$ & RH [\%] & SWD $\left[\mathrm{W} \mathrm{m}^{-2}\right.$ ] & CC [octas] & $T_{\text {prec }}\left[\mathrm{mm} \mathrm{day}^{-1}\right]$ & $T_{\max }\left[{ }^{\circ} \mathrm{C}\right]$ & $\mathrm{PO}[\mathrm{hPa}]$ & $T_{\max }\left[{ }^{\circ} \mathrm{C}\right]$ & $\mathrm{RH}[\%]$ & CC [octas] \\
\hline Min. & -78.58 & -0.02 & 5.98 & -44.24 & -0.04 & 0 & -0.81 & -5.52 & 0.72 & 16.47 & -0.22 \\
\hline 5th Perc. & -80.27 & -0.82 & 2.9 & -48.28 & -0.08 & 0 & -1.5 & -2.15 & -2.6 & 13.69 & -0.31 \\
\hline 95th Perc. & -16.68 & -1.66 & 4.09 & -8.92 & 0.4 & 0.05 & -3.87 & -0.08 & -1.99 & 8.74 & 0.04 \\
\hline Max. & -3.23 & -0.72 & 3.64 & -10.87 & -0.42 & 0.05 & -3.87 & 2.2 & -1.34 & 14.75 & 0.05 \\
\hline
\end{tabular}



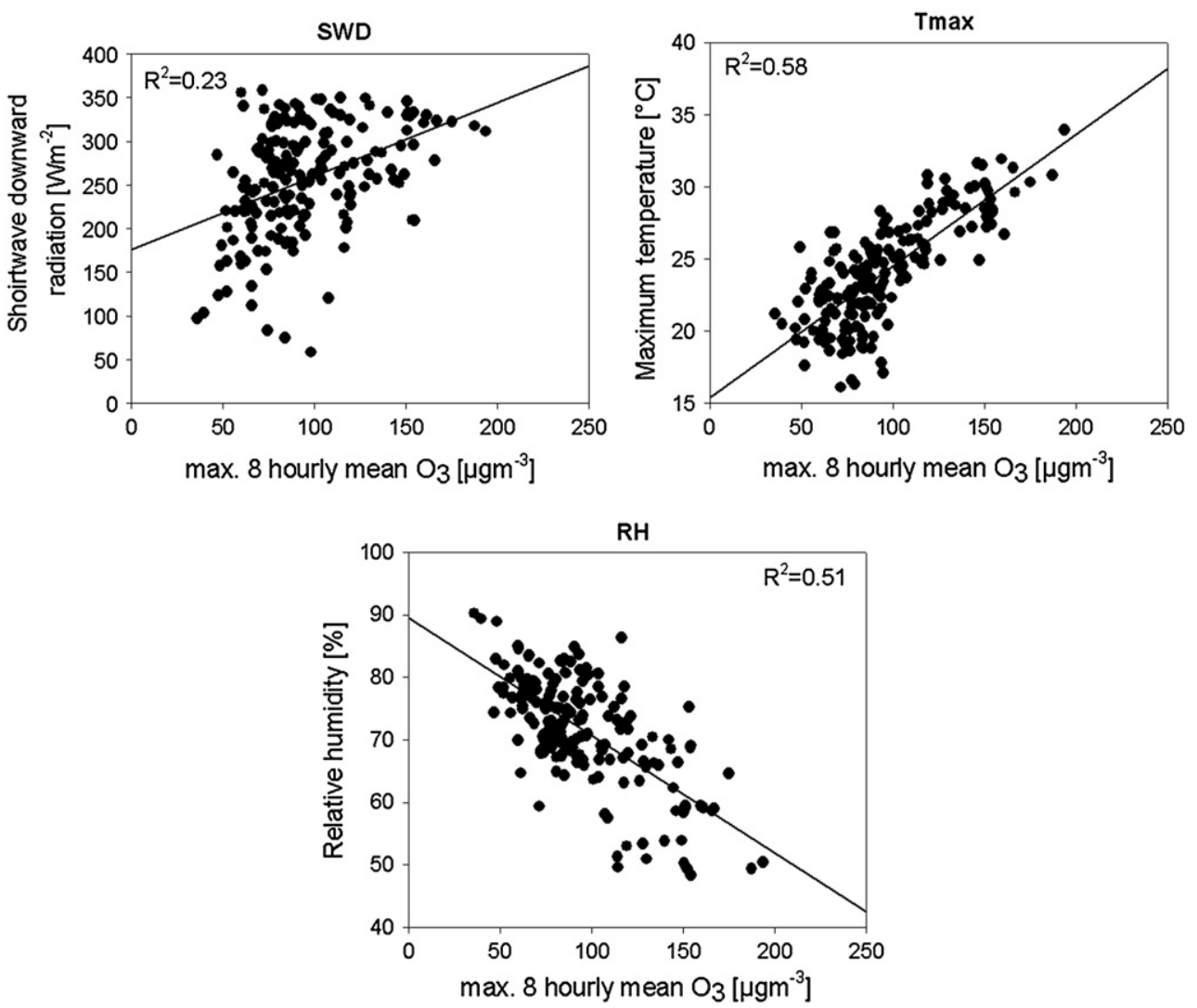

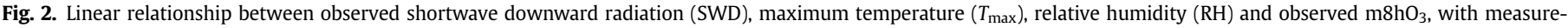
ments taken from the period 2001-2006 (Part I). Data are shown for the patterns A, E, SE and S grouped together, only for summer.

\subsection{Objective lamb circulation patterns (1991-2000)}

First, the objective Lamb circulation patterns (Jones et al., 1993; Demuzere et al., 2008) are derived for both ERA40 and ECHAM5 sea level pressure fields for the period 1991-2000 (Fig. 3). The spatial agreement of the circulation patterns derived from ERA40 and ECHAM5 is good, with a similar location of the high and lowpressure systems for each circulation type.

Nevertheless, there are some differences in the strength of the pressure systems, resulting in differences in frequencies of occurrence for some circulation patterns (Fig. 4). To assess whether these differences are significant over all types per month and for each type over the whole year, the $\chi^{2}$ test is applied using a 0.1 significance level (Chernoff and Lehmann, 1954). The difference in overall frequency distribution of the ECHAM5 circulation types per month is insignificant different $(P>0.1)$ compared to the ERA40 observed frequency distribution, except for February $(P=0.09)$ (Fig. 4). The frequency distribution per type over the whole year only shows a significant difference in the Western circulation pattern $(P=0.04)$ between the modelled (ECHAM5) frequencies and the observed (ERA40) frequencies. Thereby, this bias in westerlies is positive (negative) in the months July, August and September (January, February, March and December) (Fig. 4). As the circulation patterns dominating high ozone concentrations (in summer) are controlled by east to south directions (Demuzere et al., 2009), this significant bias in westerlies has only a minor impact on the results of this downscaling approach.

\subsection{Downscaled $\mathrm{mBhO}_{3}$ for the present-day climate}

In part I of this paper, the synoptic-regression based approach using coarse resolution ECMWF model data was shown to have an acceptable skill in terms of explained variance, RMSE and skill score against persistence, although the higher percentiles were underestimated in comparison to the use of single grid-point higher-resolution ECMWF predictor variables. The unexplained part of the variance is due to a combination of the intrinsic limitation of a regression method to capture the higher percentiles (Wilby et al., 2004), the scale-dependency of the predictor variables and ECMWF model deficiencies. In Fig. 5, these error trends are confirmed for the period 1991-2000 using both the coarse resolution ERA40 and higher-resolution ERA40-1 predictor variables. The explained variances for both datasets are respectively 60 and $61 \%$, similar to the explained variance obtained using the 2005-2006 validation period (63\%) in Part I of this research. In contrast to the explained variance, larger differences can be found in the higher percentiles of the downscaled $\mathrm{m} 8 \mathrm{hO}_{3}$ distribution (see Fig. 11 in Part I). This can be seen from the number of days with a concentration higher than or equal to the $120 \mu \mathrm{g} \mathrm{m}^{-3}$ (EU, 2008); 62 and 79 days respectively compared to an observed 141 days over the whole period.

This effect of underestimating the higher $\mathrm{m} \mathrm{hO} \mathrm{O}_{3}$ percentiles is enhanced using ECHAM5 20C control run meteorological variables as predictors for the present-day period of 1991-2000 (Fig. 5). Although the overall mean from the prediction model using ECHAM5 19912000 predictor data is similar compared to the observations ( 54.6 vs $55.2 \mu \mathrm{g} \mathrm{m}^{-2}$ ), the standard deviation is significant smaller (of $24.0 \mathrm{vs}$. $31.6 \mu \mathrm{g} \mathrm{m}^{-2}$ ). This difference is due to an overestimation of the lower $\mathrm{m} 8 \mathrm{hO}_{3}$ percentiles in the ECHAM5 model, which in general have a higher frequency of occurrence compared to the higher percentiles. In contrast, the higher percentiles are largely underestimated, which can be seen from for e.g. the number of days that are exceeding the $120 \mu \mathrm{g} \mathrm{m}^{-3}$ threshold (21 days). 

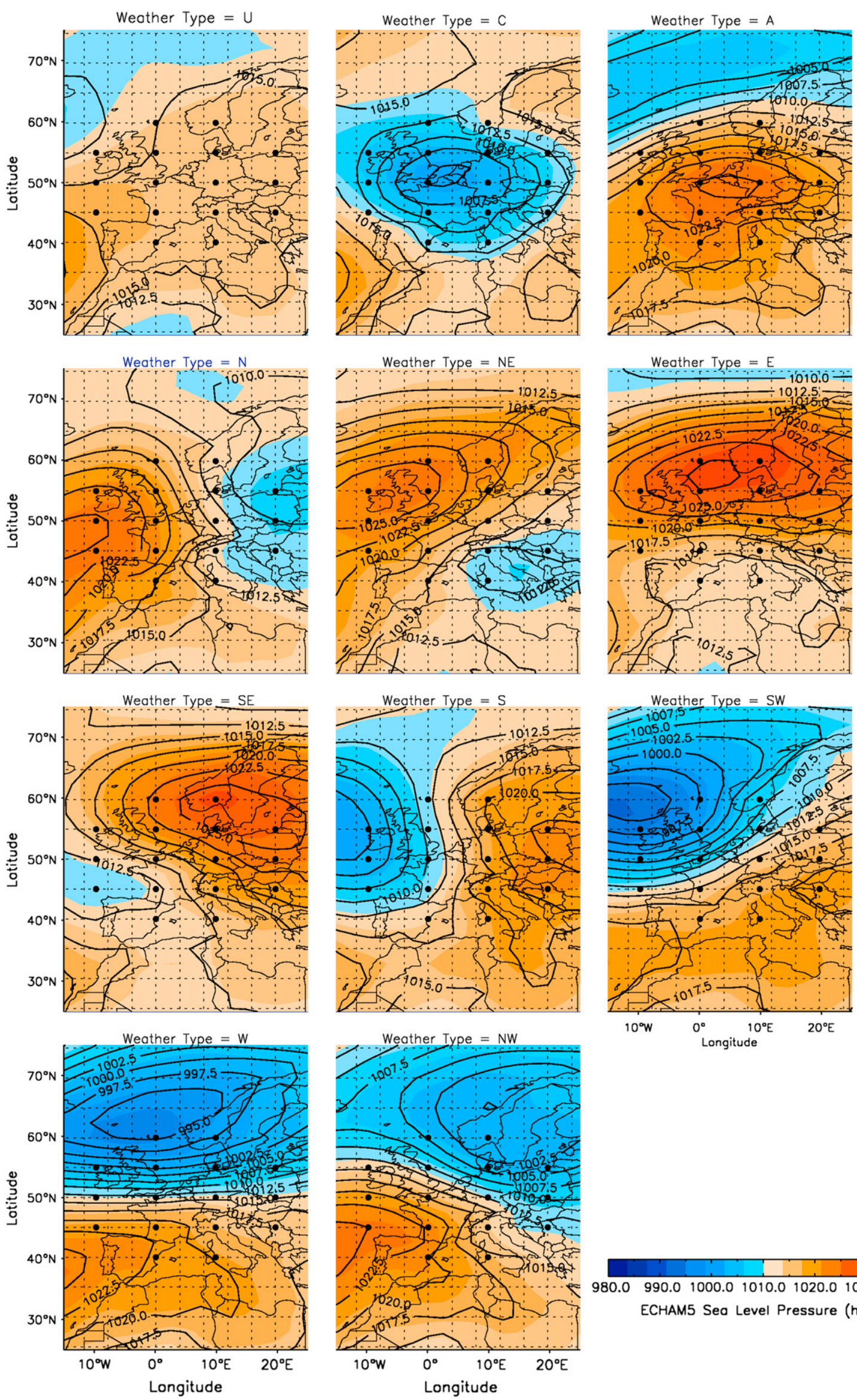

$980.0990 .01000 .0 \quad 1010.01020 .01030 .01040 .0$

ECHAM5 Seo Level Pressure ( $\mathrm{hPo}$ )

Fig. 3. Composite maps for the circulation patterns derived from ERA40 SLP (black lines) and ECHAM5 20C control run (shaded colors) for the period 1991-2000. (For interpretation of the references to colour in this figure legend, the reader is referred to the web version of this article.) 

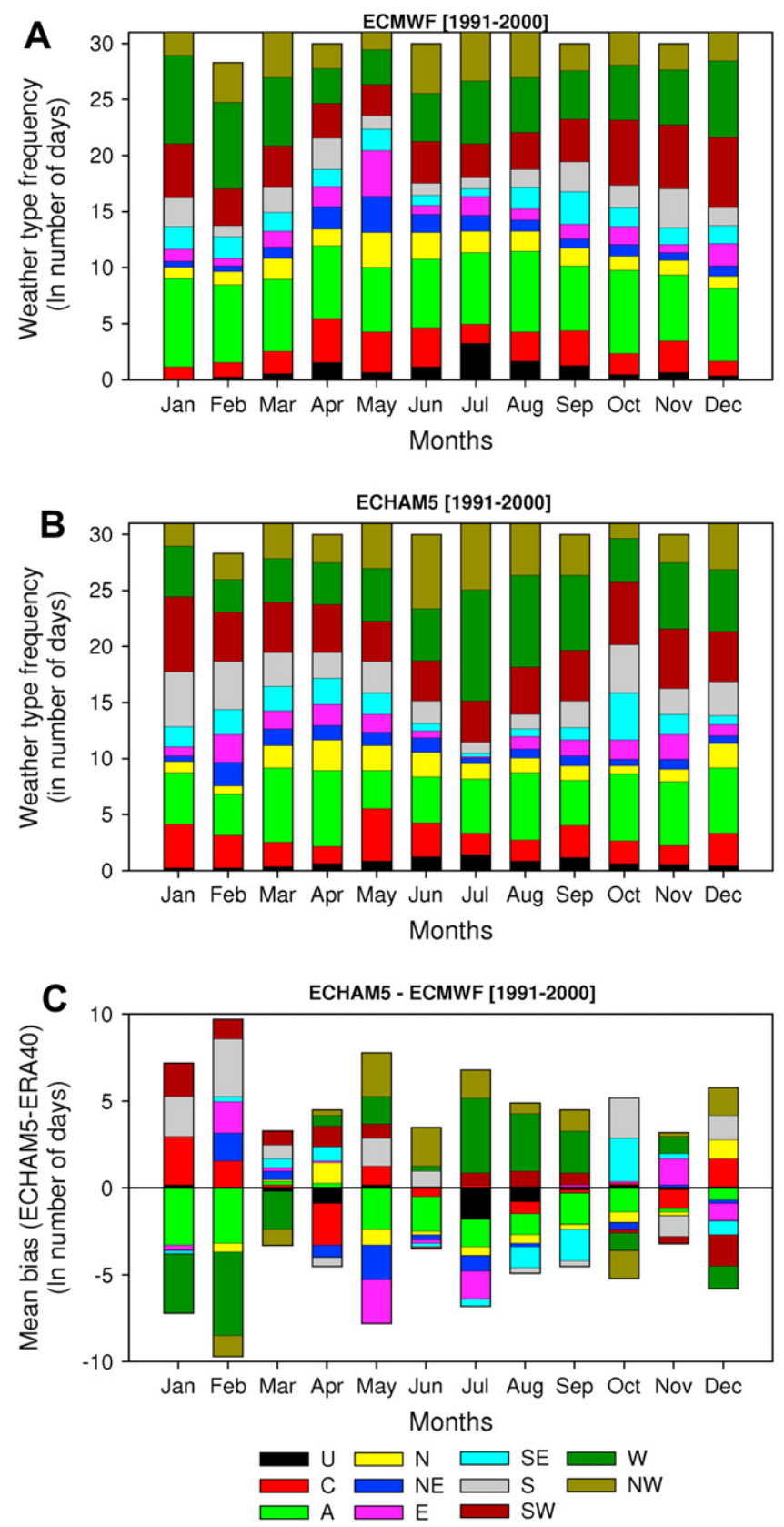

Fig. 4. Bar chart showing the frequencies (in mean number of days per month) for each circulation pattern for ECMWF (A.), ECHAM5 (B.) and the ECHAM5-ECMWF difference (C.) for the period 1991-2000. (For interpretation of the colour plots and legend, the reader is referred to the web version of this article.)

Section 4.1 has shown that there are no significant differences between modelled and observed Lamb circulation patterns for the period 1991-2000, except for February. As this month is characterized by a relatively low concentration of $\mathrm{m} 8 \mathrm{hO}_{3}$ (Fig. 6), this difference in circulation pattern frequencies cannot explain the large underestimation of the higher $\mathrm{O}_{3}$ percentiles by ECHAM5. As mentioned previously, the reason for the differences in observed and downscaled $\mathrm{m} \mathrm{hO}_{3}$ is partly due to the representation of the meteorological variables by the model that are used in the statistical downscaling process. Hence, ECHAM5 summer (JJA) predictor values are compared with the ERA40-1 JJA predictors. This is done for the patterns A, E, SE and S only, as they are associated with the highest concentrations in summer (Table 1 ).

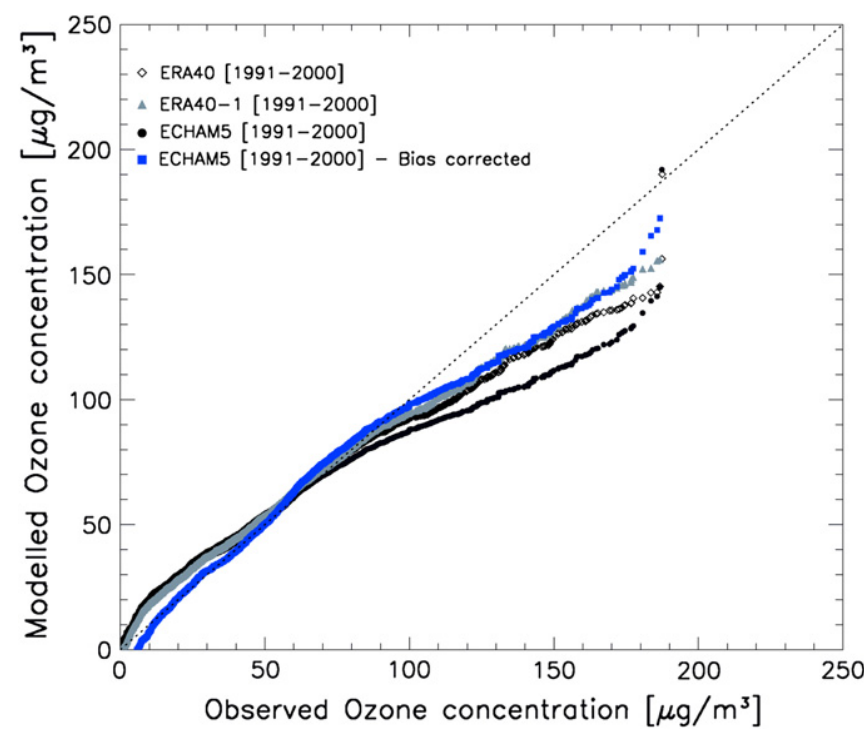

Fig. 5. Quantile-quantile plot showing observed versus downscaled $\mathrm{m} 8 \mathrm{hO}_{3}$ concentrations using ERA40 (diamonds), ERA40-1 (gray triangles) and ECHAM5 (black circles) predictor data for the period 1991-2000. The bias-corrected ECHAM5 downscaled $\mathrm{O}_{3}$ is shown in blue. The perfect model ( $1: 1$ line) is shown as the dashed line. (For interpretation of the references to color in this figure legend, the reader is referred to the web version of this article.)

For the anticyclonic pattern, ECHAM5 underestimates (overestimates) all statistical indices for SWD and $T_{\max }(\mathrm{RH})$, with a largest difference for temperature for the 95th percentile $\left(1.66^{\circ} \mathrm{C}\right)$. For the eastern circulation patterns, ECHAM5 (under) overestimates the mean amount of cloud cover in the (lower) higher percentiles, associated with an overall underestimation of SWD in ECHAM5. For both circulation patterns this results in a reduced ozone formation, as cloud cover and RH (SWD and $T_{\max }$ ) reduces (stimulates) the photochemical ozone production. The southeastern pattern is associated with a small overestimation in the precipitation distribution statistics and too low maximum temperatures in ECHAM5 compared to the observed ERA40-1 values, especially in the 95th percentile $\left(-3.87^{\circ} \mathrm{C}\right)$ and maximum $\left(-3.87^{\circ} \mathrm{C}\right)$ (Table 1$)$. Again, both features contribute to an underestimation of downscaled $\mathrm{m}^{8 \mathrm{hO}_{3}}$.

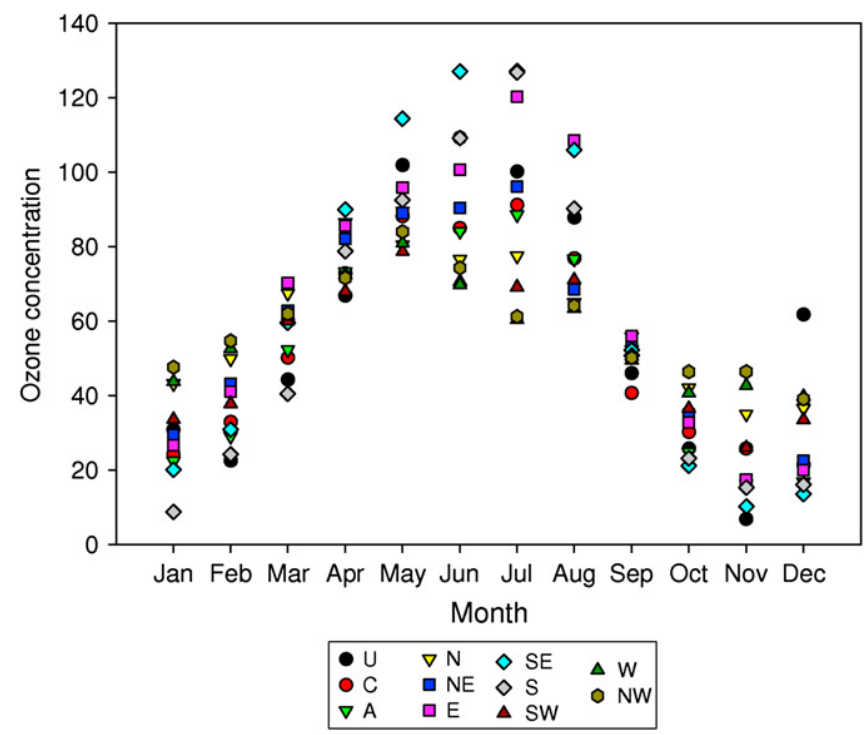

Fig. 6. Mean ozone concentration for each month and specific circulation pattern separately, averaged over the period 1991-2000. 
Also for the southern pattern, ECHAM5 is characterized by lower $T_{\max }$ and a general overestimation of surface pressure (P0), $\mathrm{RH}$ and cloud cover (CC) in the higher percentiles (Table 1 ). As the latter are negatively correlated to $\mathrm{m} \mathrm{hO}_{3}$, the net effect of the biases in meteorological variables dampens the production of $\mathrm{m}^{2} \mathrm{hO}_{3}$.

These differences between observed and present-day ${\mathrm{m} 8 \mathrm{hO}_{3}}_{3}$ concentrations should be addressed, in order to estimate future $\mathrm{m}^{\circ \mathrm{hO}_{3}}$ levels. Therefore, we perform a bias correction method proposed by Cheng et al. (2007), which takes into account the differences between

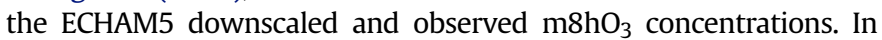
a first step (1), this is done for the present-day climate, and afterwards, the same bias correction is applied to future air pollution concentrations (2) described in Section 4.3. By doing so, we assume that the model bias in a future climate is the same as in the present-day climate. The first step in this bias correction procedure uses the following expression:

$\mathrm{O}_{3 \text { pres-new }}=\left(\mathrm{O}_{3 \text { pres-old }}-\overline{\mathrm{O}}_{3 \text { pres-old }}\right) \frac{\sigma_{\text {pres-Obs }}}{\sigma_{\text {pres-old }}}+\overline{\mathrm{O}}_{30 b s}$.

where $\mathrm{O}_{3 \text { pres-old }}$ and $\mathrm{O}_{3 \text { pres-new }}$ are daily model predictions using present-day ECHAM5 data before and after the bias correction. $\sigma_{\text {pres-Obs }}$ and $\sigma_{\text {pres-old }}$ are standard deviations of the observations and model predictions for the present-day run respectively. $\overline{\mathrm{O}}_{3 \text { pres-old }}$ and $\overline{\mathrm{O}}_{30 b s}$ are respectively the means of the present-day downscaled and observed $\mathrm{O}_{3}$ time series. In this way, the mean and standard deviation of $\mathrm{O}_{3 \text { pres-new }}$ is identical to the observed time series.

In order to know whether the model bias is spread randomly over different circulation patterns or if the $\mathrm{m} \mathrm{hO}_{3}$ bias is circulation typespecific, the significance test suggested by Raisanen et al. (2001), inferred from the t-statistics, is used which tests the significance of the circulation-type dependent bias in $\mathrm{m} 8 \mathrm{hO}_{3}$ concentration (modelled versus observed) against the type-specific internal variability. In general, there is an inhomogeneous distribution of the bias over the different circulation patterns (not shown). All patterns have a positive type-specific bias, except for the cyclonic, east and southeastern patterns. Nevertheless, all t-values are low, which indicates that the type-specific bias is insignificant compared to the type-specific internal ${\mathrm{m} 8 \mathrm{hO}_{3}}_{3}$ variability. Hereby, a high bias is often associated with a high internal variability (e.g. types E and SE). Therefore, the bias correction method (1) is applied for the whole year, without taking into account the type-specific biases.

After the bias correction the results improve significantly, especially for the higher percentiles (Fig. 5). This can be seen again from the number of days that are higher than or equal to the $120 \mu \mathrm{g} \mathrm{m}^{-3}$ threshold: from 21 days decade ${ }^{-1}$ in the original present-day downscaled $\mathrm{m} 8 \mathrm{hO}_{3}$ concentration time series to 79 days decade ${ }^{-1}$ for the bias-corrected $\mathrm{m}^{8 \mathrm{hO}_{3}}$ levels, identical to using the ERA40-1 predictor variables. Moreover, the bias-corrected ECHAM5 $\mathrm{m} 8 \mathrm{hO}_{3}$ series is closer to the perfect model line (1:1 line) in the lower and higher percentiles (Fig. 5). As there is still a considerable underestimation in the number of days exceeding the threshold (79 vs. 141 days), even after the bias correction, the results found here are likely to be a lower boundary of (future) ozone exceedences.

\subsection{Downscaled future $\mathrm{mshO}_{3}$ levels}

Daily $\mathrm{m} 8 \mathrm{hO}_{3}$ concentrations for two future periods - 2051-2060 and 2091-2100 - are estimated using the statistical synopticregression based approach with the future SRES A2, A1B and B1 scenarios and associated future circulation patterns. According to the removal of the bias in the first step (1), the differences in overall means $\left(\overline{\mathrm{O}}_{3}\right)$ and standard deviations $(\sigma)$ between the after (presnew) and before (pres-old) correction of the present-day downscaled ${\mathrm{m} 8 \mathrm{hO}_{3}}_{3}$ are used to adjust future $\mathrm{m} 8 \mathrm{hO}_{3}$ concentrations $\left(\mathrm{O}_{3 \text { fut-old }}\right)$ in a second step (2) using the following equation:

$\mathrm{O}_{3 f u t-n e w}=\left(\mathrm{O}_{3 \text { fut-old }}-\overline{\mathrm{O}}_{3 \text { pres-old }}\right) \frac{\sigma_{\text {pres-new }}}{\sigma_{\text {pres-old }}}+\overline{\mathrm{O}}_{3 \text { pres-new }}$.

Hereby, $\mathrm{O}_{3 \text { fut-new }}$ present future daily model prediction after the bias correction, assuming that the model bias in the future will be similar to the bias in the present-day climate. This results in a downscaled bias-corrected ozone concentration for the three SRES climate change scenarios for the periods 2051-2060 and 2091-2100. Under the various SRES scenarios, the overall mean ${\mathrm{m} 8 \mathrm{hO}_{3}}_{3}$ increases with 2.5-6.5 and 6.1-10.9 $\mu \mathrm{g} \mathrm{m}^{-3}$, for the 20512060 and 2091-2100 periods respectively, against the present-day 10 -year average of $55.2 \mathrm{\mu g} \mathrm{m}^{-3}$ (not shown). When considering the summer season only, the range of change over all scenarios increases with 5.4-12.5 $\mu \mathrm{g} \mathrm{m}^{-3}$ and 13.4-26 $\mu \mathrm{g} \mathrm{m}^{-3}$ (for 2051-2060 and 2091-2100 respectively) against a present-day summer average of $73.5 \mu \mathrm{g} \mathrm{m}^{-3}$ (not shown).

In addition to changes in mean concentrations, changes in the number of days within low, moderate and high levels of $\mathrm{m} 8 \mathrm{hO}_{3}$ seen over a whole year are of interest to the public and policy makers (Table 2). The application of different emission scenarios has a variable impact on the number of days in each specific $\mathrm{m} 8 \mathrm{hO}_{3}$ category. By the middle and end of this century, the number of days with high levels of $\mathrm{m}^{2} \mathrm{hO}_{3}$ could increase in a range of 4.3-12.3 day $\mathrm{yr}^{-1}$ and 7.1-21.1 day $\mathrm{yr}^{-1}$ respectively, with the highest increase against the 2050s (end of the century) for the A2 (A1B) scenario. A similar effect can be seen for the days with a moderate $\mathrm{m} 8 \mathrm{hO}_{3}$ concentration, varying between 1.7 and 9.2 day $\mathrm{yr}^{-1}$ and 9-14.8 day $\mathrm{yr}^{-1}$ for the periods 2051-2060 and 2091-2100 respectively. This is counteracted by a strong decrease in the number of days with low concentrations by the 2050s and 2090s respectively. Fig. 7 depicts the large scatter when applying the different SRES scenarios. Here, the absolute number of days exceeding the $120 \mu \mathrm{g} \mathrm{m}^{-3}$ threshold in the present-day climate is given, together with the change in number of days exceeding this threshold by the middle and end of this century. The error bars present the lowest/highest change over the three

Table 2

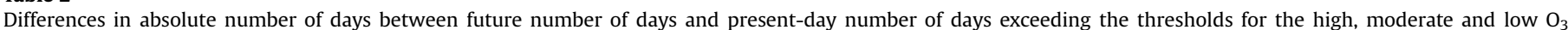

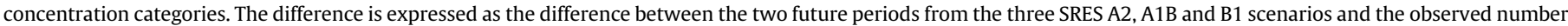
of days in 1991-2000. The scenario with the highest increase (decrease) in $\mathrm{O}_{3}$ concentration for each future period are denoted in bold (italic).

\begin{tabular}{|c|c|c|c|c|c|c|c|c|}
\hline \multirow{2}{*}{\multicolumn{2}{|c|}{ Category $\left[\mu \mathrm{g} \mathrm{m}^{-3}\right]$}} & \multirow[t]{2}{*}{ No. Of days (observed) } & \multicolumn{2}{|l|}{$\mathrm{A} 2$} & \multicolumn{2}{|l|}{$\mathrm{A} 1 \mathrm{~B}$} & \multicolumn{2}{|l|}{ B1 } \\
\hline & & & 2051-2060 & $2091-2100$ & $2051-2060$ & $2091-2100$ & $2051-2060$ & 2091-2100 \\
\hline & & & days & days & days & days & days & days \\
\hline $\operatorname{High}^{\mathrm{a}}$ & $\geq 120$ & 13.7 & 9.5 & 12.7 & 4.3 & 21.2 & 4.5 & 7.1 \\
\hline Moderate $^{\mathrm{b}}$ & $80-120$ & 39.8 & 9.2 & 12.2 & 4.7 & 14.8 & 1.7 & 9.0 \\
\hline Low $^{c}$ & $<80$ & 266.3 & -18.7 & -24.9 & -9.0 & -36.0 & -6.2 & -16.1 \\
\hline
\end{tabular}

a Days with ${\mathrm{m} 8 \mathrm{O}_{3}}_{3}$ higher than or equal to $120 \mu \mathrm{g} \mathrm{\textrm {m } ^ { - 3 }}$.

b Days with ${\mathrm{m} 8 \mathrm{O}_{3}}_{3}$ between 80 and $120 \mu \mathrm{g} \mathrm{m}^{-3}$.

c Days with $\mathrm{m} 8 \mathrm{O}_{3}$ lower than $80 \mu \mathrm{g} \mathrm{m}^{-3}$. 


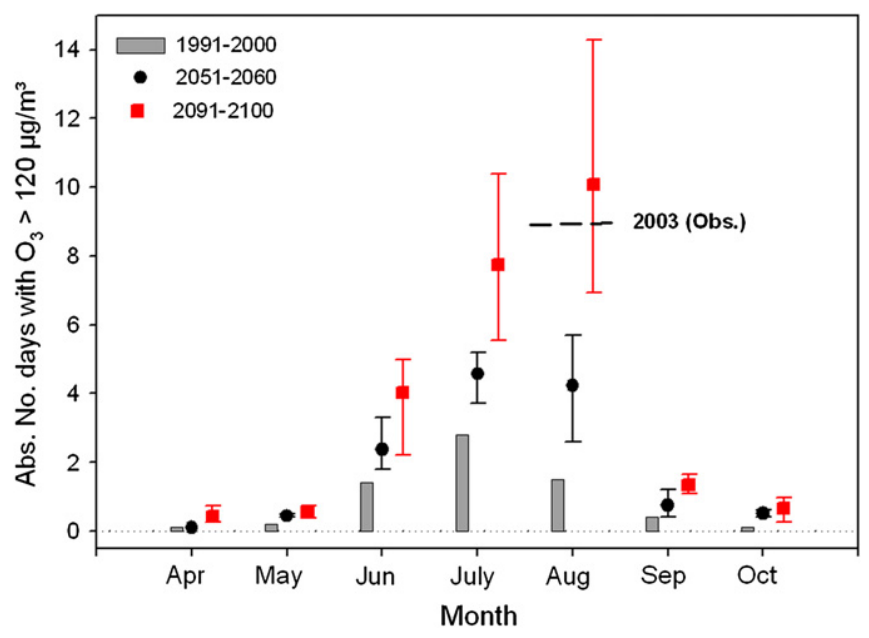

Fig. 7. Monthly variability of the number of days per month exceeding the $120 \mu \mathrm{g} \mathrm{m}^{-3}$ threshold for the present-day climate and future climate SRES scenarios, for the periods 2051-2060 and 2091-2100. The number of exceedences is denoted as absolute values per month. The short black dashed line indicates the number of observed exceedences in August 2003 in Cabauw.

scenarios, while the average change is calculated as the mean change over the three scenarios. Thus, on average, there is an increase of 2.2, 4.2 and 4.0 (3.2, 6.3 and 8.5) days month ${ }^{-1}$ exceeding this threshold for June, July and August 2051-2060 (2091-2100) respectively. The error bars present a large uncertainty depending on the future scenario, with a maximum variability of 4 days month ${ }^{-1}$ by the 2050 s almost 7 days month ${ }^{-1}$ by the end of the century. Taking into account the underestimation of numbers of days exceeding the threshold in the present-day climate, the increase in number of days exceeding the threshold by the end of the century should be considered as a lower boundary of the sensitivity analysis. A possible strategy to address this in the future is to take into account multiAOGCM ensembles runs.

\section{Discussion}

As the synoptic-regression based approach does not take into account emissions as predictor values, the change in number of days with moderate and high downscaled $\mathrm{m}^{8} \mathrm{hO}_{3}$ concentrations between the future SRES scenarios and the present-day 20C climate run can be caused by two interrelated effects: 1) a change in frequency of those circulation patterns favoring high $\mathrm{O}_{3}$ concentrations and 2) a change in meteorological predictor values regulating the production of ozone in the type-specific regression analysis (Table 3 and Fig. 8).

\section{Table 3}

The mean predictor values and their individual influence in the synoptic-regression based approach on the resulting downscaled $\mathrm{m} \mathrm{hOO}_{3}$ concentration, averaged for the A, E, SE and S circulation patterns in summer. The percentage of $\mathrm{m} 8 \mathrm{hO}_{3}$ changes between the future SRES climate periods and the downscaled $\mathrm{m} \mathrm{hOO}_{3}$ concentration for the reference period are given in brackets.

\begin{tabular}{|c|c|c|c|c|c|}
\hline & \multirow{2}{*}{$\begin{array}{l}\text { Predictor mean } \\
(1991-2000)\end{array}$} & \multicolumn{4}{|c|}{$\mathrm{O}_{3}$ concentrations } \\
\hline & & \multicolumn{2}{|c|}{$\begin{array}{l}2051-2060 \text { to } \\
1991-2000 \mu \mathrm{g} \mathrm{m}^{-3}(\%)\end{array}$} & \multicolumn{2}{|c|}{$\begin{array}{l}2091-2100 \text { to } \\
1991-2000 \mu \mathrm{g} \mathrm{m}^{-3}(\%)\end{array}$} \\
\hline$\overline{\mathrm{P0}[\mathrm{hPa}]}$ & 1020.2 & 0.7 & $(4.1)$ & 0.6 & $(1.8)$ \\
\hline Tprec $\left[\mathrm{mm} \mathrm{day}^{-1}\right]$ & 0.0 & 0 & $(0)$ & 0 & $(0)$ \\
\hline $\mathrm{SWD}\left[\mathrm{W} \mathrm{\textrm {m } ^ { - 2 } ]}\right.$ & 216.1 & 1.7 & $(9.9)$ & 4.6 & $(14.5)$ \\
\hline$T_{\max }\left[{ }^{\circ} \mathrm{C}\right]$ & 22.8 & 6.8 & (39.1) & 13.9 & $(43.78)$ \\
\hline $\mathrm{RH}[\%]$ & 76.7 & 3 & (17.3) & 4.7 & (15) \\
\hline CC [octas] & 3.1 & 5.1 & $(29.6)$ & 7.9 & (24.9) \\
\hline
\end{tabular}

In order to test the sensitivity of future ozone levels to the change in frequency of occurrence of the future Lamb circulation patterns, the Mann-Kendall test is used to calculate the trends in JJA frequencies of $A, E, S E$ and $S$ circulation patterns for the period 2001-2100. As it is shown in Demuzere et al. (2008), there is a large interannual variability between the three future SRES scenarios without a significant difference in their future trends and frequencies. Hence, we opt to test the A1B scenario only with respect to future circulation pattern frequencies. This trend analysis shows an increasing frequency insignificant at the $90 \%$ level $(0.87$ number of days $\mathrm{yr}^{-1}$ ). As this trend analysis shows no significant change in the frequency of occurrence of these specific circulation patterns leading to high ozone concentrations, the change in the individual meteorological variables between the different periods is investigated. Fig. 8 depicts the cumulative frequency distribution for the predictor variables that occur most frequently in summer (Part I - Table 1). Here, the SRES scenarios A1B and A2 show the highest increase in maximum temperature, with an averaged increase of $4.8{ }^{\circ} \mathrm{C}$ in August by the end of this century (Fig. 8). Furthermore, all scenarios show a reduction of cloud cover (not shown), as described in Meleux et al. (2007) and Forkel and Knoche (2007), which is associated with an increase in future shortwave downward radiation (Meleux et al., 2007) (Fig. 8). The change in relative humidity is rather small, with generally a decreasing trend, strongest in August and by the end of this century.

To estimate the individual contribution of each predictor variable, a sensitivity experiment is performed for all circulation patterns conducive for high $\mathrm{m} 8 \mathrm{hO}_{3}$ concentrations in summer (Table 3). For each predictor variable, the present-day median is replaced by its future value, while keeping the other predictor variables to their present-day levels. Thereby, the predictor variables are perturbed with the difference between future and present-day medians (for the A, E, SE and E patterns), averaged over the three scenarios, which provides a measure for the individual contribution of each predictor variable to the change in future $\mathrm{m} \mathrm{hO}_{3}$ concentration. In general, the maximum temperature has the largest contribution, with an ozone increase of 6.8 and $13.9 \mu \mathrm{g} \mathrm{m}^{-3}$ by the middle and end of this century respectively (respectively 39.1 and $43.8 \%$ of the change). The highest frequency of occurrence for this predictor in the regression model shown in Part I of this research (Table 1 therein) denotes the importance of this variable on $\mathrm{m} \mathrm{hO}_{3}$ concentrations in a future climate. Furthermore, the strong linear trend of $T_{\max }$ depicted in Fig. 2 gives confidence in the robustness of the statistical downscaling tool, as a future climate tends to show a shift towards higher maximum temperatures Schär et al. (2004), which are linearly related to ${\mathrm{m} 8 \mathrm{hO}_{3}}_{3}$ concentrations (under the assumption that present-day relations will be similar in the future). The contribution of the shortwave radiation increases between the middle and end of this century with $4.6 \%$, to an increase of $14.5 \mu \mathrm{g} \mathrm{m}^{-3}$ for the period 2091-2100. The decrease in relative humidity (cloud cover) results in an average ozone concentration increase of 3 and $4.7 \mu \mathrm{g} \mathrm{m}^{-3}$ (5.1 and $7.9 \mu \mathrm{g} \mathrm{m}^{-3}$ ), which accounts for respectively 17.3 and 15\% (29.6 and $24.9 \%$ ) of the total change. The mean sea level pressure P0 and total precipitation only contribute marginally to the total change.

In order to verify whether these findings are physically plausible, our results are compared with the observed heat wave in August 2003, characterized by a poor air quality (especially in terms of $\mathrm{O}_{3}$ ) and excess of mortalities in large parts of Western and Central Europe (WHO, 2005), In this respect, Schär et al. (2004) suggested, based on regional climate model scenarios for the period 2071-2100, that about every second summer at the end of this century could be as warm or warmer than 2003. During this 2003 August, 9 days exceeded the threshold of $120 \mu \mathrm{g} \mathrm{m}^{-3}$ in Cabauw, which lies in the upper range of the number of exceedences for the 2050s and corresponds closely to the mean number of exceedences 


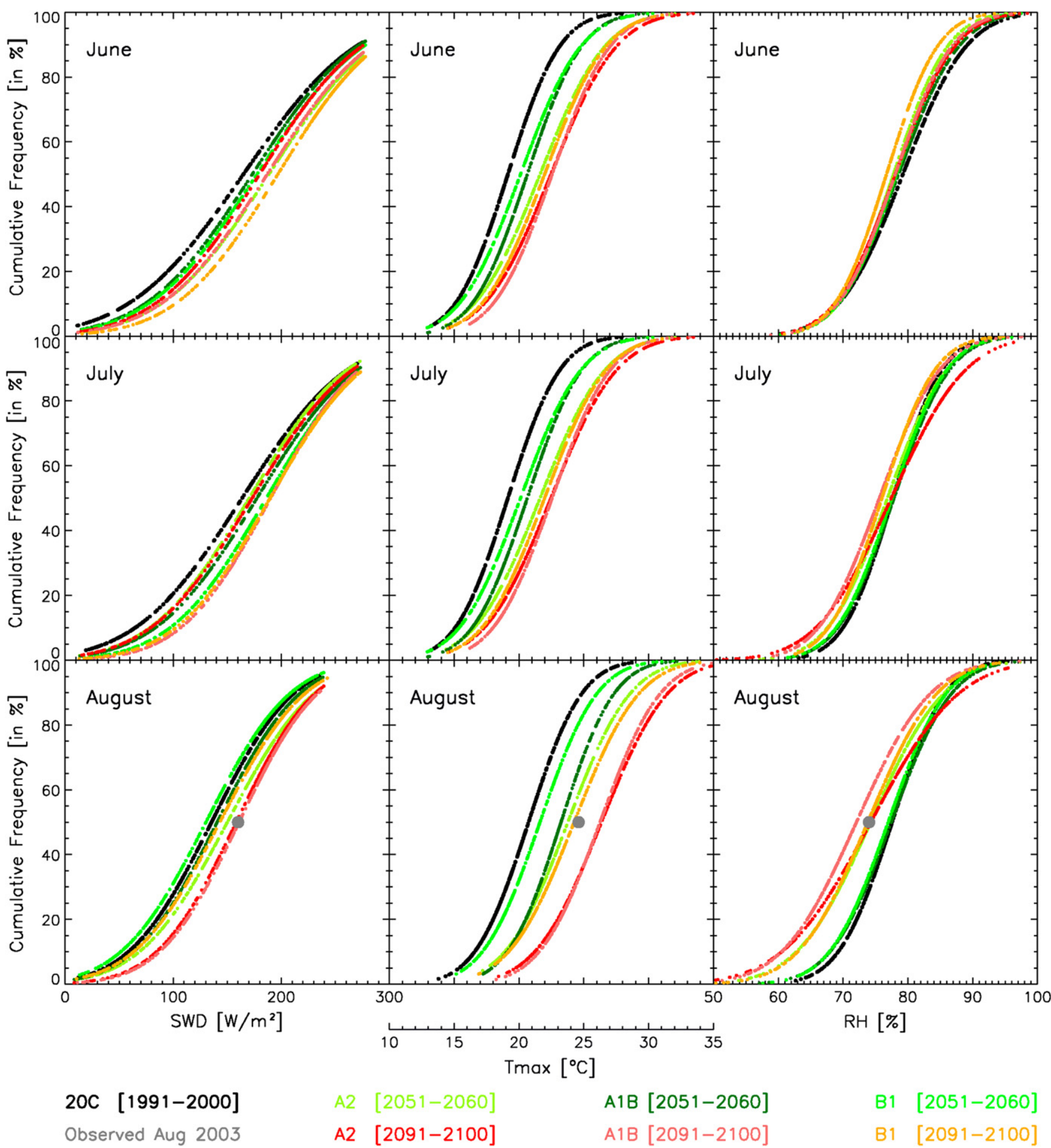

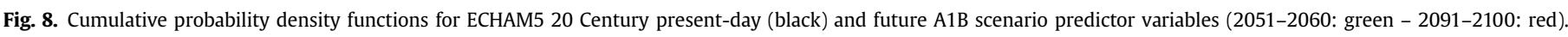

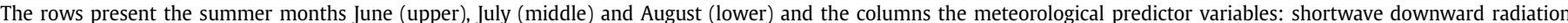

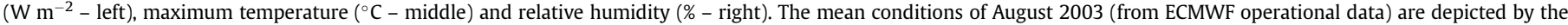
filled gray dot. (For interpretation of the references to color in this figure legend, the reader is referred to the web version of this article.)

by the end of this century (9.7 days month ${ }^{-1}$ ) (Fig. 7). This is confirmed by the exceptional warm and dry weather during August 2003, which characteristics corresponds to ECHAM5 scenarios by the end of this century (Fig. 8). For shortwave downward radiation, the August 2003 values correspond to the A2 and A1B scenarios, while for $\mathrm{RH}$ and $T_{\max }$, the observed values correspond more closely to the B1 scenario (Fig. 8). This suggests, that, not only in terms of temperature as was shown by Schär et al. (2004), but also in terms of $\mathrm{O}_{3}$, the August 2003 conditions could become representative for future conditions.

An important assumption in our statistical approach is that the present-day meteorology - air quality relations remain constant in the future. To some extent, some interactions are indirectly taken into account using meteorological information from the AOGCMs driven 
by future SRES scenarios. Nevertheless, other features will play a role in ozone formation in a future climate. For example, a possible fastening of ozone production due to the temperature-dependency of the chemical ozone reaction rates and an increase of biogenic isoprene emissions due to a drying out of soils and vegetated surfaces (Lee et al., 2006) under increasing temperatures. On the other hand, climate change could reduce $\mathrm{O}_{3}$ concentrations by e.g. a more vigorous hydrologic cycle leading to an increase in cloudy days. The abovementioned features are hard to cope with in statistical downscaling approaches, as the latter cannot take into account these (natural/ anthropogenic) changes in emissions because of constant air-quality and meteorology transfer functions that are based on present-day information. Hence, the results of this study should not be considered as predictions of future air-quality levels associated with climate change. Rather, they demonstrate the sensitivity of atmospheric air pollutants to changes in large-scale atmospheric dynamics and specific meteorological variables. In this respect, the statistical method provided is relevant in the future air-quality debate because of its simplicity, physical interpretability and computational efficiency.

\section{Conclusion}

The synoptic-regression based downscaling approach developed in Part I of this study is used to estimate future $\mathrm{m}^{2} \mathrm{hO}_{3}$ concentrations for areas in Western Europe based on meteorological predictor variables from ECHAM5 (scenarios A2, A1B and B1) for the 2 future periods 2051-2060 and 2091-2100. Although only one AOGCM is considered here, the conditions used are in line with those projected by most other global models (Giorgi and Bi, 2005). It should however be noted that by taking into account only one GCM, the range of uncertainty might be underestimated in comparison to the use of multiple AOGCM outputs. Furthermore, any information on biogenic and anthropogenic emissions is not explicitly taken into account, but is implicitly mimicked by $T_{\max }$. Although the capabilities of the downscaling method were tested thoroughly in Part I using coarse resolution meteorological ECMWF variables, it appears that results deteriorate when using ECHAM5 meteorological data. Therefore, it is necessary to apply a bias correction method that takes into account the differences between the ECHAM5 downscaled $\mathrm{m}^{8 \mathrm{hO}_{3}}$ and observed $\mathrm{m}_{3} \mathrm{hO}_{3}$ distribution quantities. After bias correction, the overall mean $\mathrm{m}^{8} \mathrm{hO}_{3}$ increases by $2.5-6.5$ and $6.1-10.9 \mu \mathrm{g} \mathrm{m}^{-3}$ over the various scenario periods 2051-2060 and 2091-2100 respectively, against a present-day 10 -year average of $55.2 \mu \mathrm{g} \mathrm{m}^{-3}$. When considering the summer season only, the impact of climate change is considerably larger. In terms of number of days exceeding the threshold set by the European Guidelines on Air Quality, the number of days with high levels of $\mathrm{m} \mathrm{hOO}_{3}\left(>120 \mu \mathrm{g} \mathrm{m}^{-3}\right)$ could increase by the middle and end of this century in a range of 4.3-12.3 day $\mathrm{yr}^{-1}$ and 7.1-21.1 day $\mathrm{yr}^{-1}$ respectively.

The changes in $\mathrm{m} 8 \mathrm{hO}_{3}$ obtained from our statistical downscaling approach are mainly due to a positive shift in the frequency distribution of the meteorological variables driving the high ozone concentrations. In this respect, an increase in maximum temperature has been shown to be the main driver for an increase in $\mathrm{m} 8 \mathrm{hO}_{3}$, together with an increase of shortwave downward radiation and an overall decrease in cloud cover. And although the different SRES scenarios project a large variability in the various predictors, the overall changes result in a significant increase in ozone concentrations. In order to verify whether these findings are physically plausible, our results are compared with the observed heat wave in August 2003. This shows that for the main predictors driving high ozone concentrations, the observed values fit closely to the predictor's future distributions, taking into account the given scenario assumptions. Thus, the 2003 heat wave, with related high $\mathrm{m} 8 \mathrm{hO}_{3}$ concentrations, can serve as an analogue to what may occur more regularly in the future, not only in terms of temperature, but also in terms of ${\mathrm{m} 8 \mathrm{hO}_{3}}_{3}$.

This paper studies the impact of global climate change on future $\mathrm{O}_{3}$ levels only, without taking into account future changes (reductions) in emissions. We have shown here that, under changing atmospheric conditions, the $\mathrm{m} \mathrm{hO}_{3}$ concentration increases significantly by the end of this century, assuming present-day emissions, which are indirectly taken into account in the statistical downscaling tool. Here, the question arises whether current emission control strategies will be sufficient to reduce $\mathrm{O}_{3}$ precursor levels in order to keep the future $\mathrm{O}_{3}$ concentrations below the European thresholds. In this respect, future climate changes should be taken into account in the decision process on the European thresholds of Air Quality, and the thresholds should be set equal or lower in the future to protect the human health and the natural environment. After all, ozone is the third most important man-made greenhouse gas after $\mathrm{CO}_{2}$ and methane. Furthermore, joint efforts should be done first to develop an integrated model set-up in order to quantify air-quality levels under changing climate conditions. This should be done in order to set-up appropriate emission reduction measures to achieve acceptable ozone levels in the future, both on local, regional and the global scale.

\section{Acknowledgments}

This research is funded by a PhD grant of the Institute for the Promotion of Innovation through Science and Technology Flanders (IWT-Flanders). Furthermore, it was conducted in the framework of the CLIMAQS project, with financial support of the Institute for the Promotion of Innovation by Science and Technology in Flanders (IWT-Flanders). ECMWF is acknowledged for providing operational ECMWF data. Furthermore I gratefully thank Fred Bosveld (KNMI) and Jan Matthijsen (RIVM) in providing the Cabauw meteorological and ozone observations respectively. Furthermore, the comments of Michiel Roemer (TNO) on the $\mathrm{O}_{3}$ measurements from Cabauw are gratefully appreciated. Finally, I would like to thank the two anonymous reviewers for their interesting comments on the manuscript.

\section{References}

Alexandersson, H., Moberg, A., 1997. Homogenization of Swedish temperature data 1. Homogeneity test for linear trends. International Journal of Climatology 17 , 25-34.

Cheng, C.S.Q., Campbell, M., Li, Q., Li, G.L., Auld, H., Day, N., Pengelly, D., Gingrich, S., Yap, D., 2007. A synoptic climatological approach to assess climatic impact on air quality in South-central Canada. Part II: future estimates. Water, Air, and Soil Pollution 182, 117-130.

Chernoff, H., Lehmann, E.L., 1954. The use of maximum likelihood estimates in $\chi 2$ tests for goodness-of-fit. The Annals of Mathematical Statistics 25, 579-586.

Demuzere, M., Werner, M., van Lipzig, N.P.M., Roeckner, E., 2008. An analysis of present and future ECHAM5 pressure fields using a classification of circulation patterns. International Journal of Climatology 29.

Demuzere, M., van Lipzig, N.P.M. A new method to assess air quality levels using a synoptic-regression approach. Part I: present analysis for $\mathrm{O}_{3}$ and $\mathrm{PM}_{10}$. Atmopsheric Environment, in press.

Demuzere, M., Trigo, R.M., Vila-Guerau de Arellano, J., van Lipzig, N.P.M., 2009. The impact of weather and atmospheric circulation on $\mathrm{O}_{3}$ and $\mathrm{PM}_{10}$ levels at a midlatitude site. Atmospheric Chemistry and Physics 9, 2695-2714.

Derwent, R.G., Jenkin, M.E., Saunders, S.M., Pilling, M.J., Simmonds, P.G. Passant, N.R., Dollard, G.J., Dumitrean, P., Kent, A., 2003. Photochemical ozone formation in north west Europe and its control. Atmospheric Environment 37, 1983-1991.

EU, 2008. Directive 2008/50/EC of the European Parliament and of the council of 21 May 2008 on ambient air quality and cleaner air for Europe. Official Journal of the European Union L 152/1.

Forkel, R., Knoche, R., 2007. Nested regional climate-chemistry simulations for central Europe. Comptes Rendus Geoscience 339, 734-746.

Giorgi, F., Bi, X., 2005. Updated regional precipitation and temperature changes for the 21st century from ensembles of recent AOGCM simulations. Geophysical Research Letters 32.

Giorgi, F., Meleux, F., 2007. Modelling the regional effects of climate change on air quality. Comptes Rendus Geoscience 339, 721-733. 
Hewitson, B.C., Crane, R.G., 1996. Climate downscaling: techniques and application. Climate Research 7, 85-95.

Jones, P.D., Hulme, M., Briffa, K.R., 1993. A comparison of Lamb circulation types with an objective classification scheme. International Journal of Climatology 13 , 655-663.

Jungclaus, J.H., Keenlyside, N., Botzet, M., Haak, H., Luo, J.J., Latif, M., Marotzke, J. Mikolajewicz, U., Roeckner, E., 2006. Ocean circulation and tropical variability in the coupled model ECHAM5/MPI-OM. Journal of Climate 19, 3952-3972.

Khaliq, M.N., Ouarda, T.B.M.J., 2007. On the critical values of the standard normal homogeneity test (SNHT). International Journal of Climatology 27, 681-687.

Lee, J.D., Lewis, A.C., Monks, P.S., Jacob, M., Hamilton, J.F., Hopkins, J.R., Watson, N.M., Saxton, J.E., Ennis, C., Carpenter, L.J., Carslaw, N., Fleming, Z., Bandy, B.J., Oram, D.E., Penkett, S.A., Slemr, J., Norton, E., Rickard, A.R., Whalley, L.K., Heard, D.E., Bloss, W.J., Gravestock, T., Smith, S.C., Stanton, J., Pilling, M.J., Jenkin, M.E., 2006. Ozone photochemistry and elevated isoprene during the UK heatwave of August 2003. Atmospheric Environment 40, 7598-7613.

Mahmud, A., Tyree, M., Cayan, D., Nehzat, M., Kleeman, M.J., 2008. Statistical downscaling of climate change impacts on ozone concentrations in California. Journal of Geophysical Research 113.

Marsland, S.J., Haak, H., Jungclaus, J.H., Latif, M., Roske, F., 2003. The Max-PlanckInstitute global ocean/sea ice model with orthogonal curvilinear coordinates. Ocean Modelling 5, 91-127.

Meleux, F., Solmon, F., Giorgi, F., 2007. Increase in summer European ozone amounts due to climate change. Atmospheric Environment 41, 7577-7587.

Nakicenovic, N., Swart, R. (Eds.), 2000. Special Report on Emissions Scenarios. Cambridge University Press, Cambridge, United Kingdom, p. 612.

Raisanen, J., Rummukainen, M., Ullerstig, A., 2001. Downscaling of greenhouse gas induced climate change in two GCMs with the Rossby Centre regional climate model for northern Europe. Tellus Series A Dynamic Meteorology and Oceanography 53, 168-191.

Roeckner, E., Bäuml, G., Boneventura, L., Brokopf, R., Esch, M., Girogetta, M., Hagemann, S., Kirchner, I., Kornblueh, L., Manzini, E., Schlese, U., Schulzweida, U., Tompkins, A., 2003. The atmospheric general circulation model ECHAM5 part I: model description.

Schär, C., Vidale, P.L., Luthi, D., Frei, C., Haberli, C., Liniger, M.A., Appenzeller, C., 2004. The role of increasing temperature variability in European summer heatwaves. Nature 427, 332-336.

Sillman, S., 1999. The relation between ozone, NOx and hydrocarbons in urban and polluted rural environments. Atmospheric Environment 33, 1821-1845.

Uppala, S.M., Kallberg, P.W., Simmons, A.J., Andrae, U., Bechtold, V.D., Fiorino, M. Gibson, J.K., Haseler, J., Hernandez, A., Kelly, G.A., Li, X., Onogi, K., Saarinen, S., Sokka, N., Allan, R.P., Andersson, E., Arpe, K., Balmaseda, M.A., Beljaars, A.C.M., Van De Berg, L., Bidlot, J., Bormann, N., Caires, S., Chevallier, F., Dethof, A., Dragosavac, M. Fisher, M., Fuentes, M., Hagemann, S., Holm, E., Hoskins, B.J., Isaksen, L., Janssen, P.A.E.M., Jenne, R., McNally, A.P., Mahfouf, J.F., Morcrette, J.J., Rayner, N.A., Saunders, R.W., Simon, P., Sterl, A., Trenberth, K.E., Untch, A., Vasiljevic, D., Viterbo, P., Woollen, J., 2005. The ERA-40 re-analysis. Quarterly Journal of the Royal Meteorological Society 131, 2961-3012.

WHO, 2005. Health and Climate Change: the 'Now and How'. A Policy Action Guide. World Health Organisation Report, Copenhagen.

Wilby, R.L., Charles, S.P., Zorita, E., Timbal, B., Whetton, P., Mearns, L.O., 2004 Guidelines for use of climate scenarios developed from the statistical downscaling methods. available from the DDC of IPCC TGCIA, 27. Available from: IPCC-DDC: http://www.ipcc-data.org.

Wilks, D.S., 1995. Statistical Methods in the Atmospheric Sciences. Academic Press, San Diego. 